\title{
Õpetajakoolituse praktikantide ja kutseaastal olevate õpetajate kutsevalikut mõjutavad motivatsioonitegurid
}

\author{
Olivia Voltri ${ }^{\mathrm{a}}$, Piret Luik ${ }^{\mathrm{a}}$, Merle Taimalu ${ }^{\mathrm{a}}$ \\ a Tartu Ülikooli haridusteaduste instituut
}

\begin{abstract}
Annotatsioon
Käesoleva uurimuse eesmärk on võrrelda õpetajakoolituse praktikantide ja kutseaastal olevate õpetajate kutsevalikut mõjutavaid motivatsioonitegureid. Kahel aastal $(2010,2012)$ korraldati uuring, kus kasutati adapteeritud FIT-Choice’i skaala varianti. Uuringus osales 396 vastajat Tartu ja Tallinna Ülikoolist (neist 189 õpetajakoolituse praktikanti, 207 kutseaastal olevat õpetajat).

Uuriva faktoranalüüsi tulemusena eristus nii õpetajakoolituse praktikantide kui ka kutseaastal olevate õpetajate kutsevaliku motiivide puhul viiefaktoriline struktuur ning kutsevalikuga rahulolu ja õpetajatööst ettekujutuse puhul kolmefaktoriline struktuur. Võrreldes õpetajakoolituse praktikantide ja kutseaastal olevate õpetajate kutsevaliku motiive t-testi alusel, leiti, et kutseaastal olevad õpetajad andsid faktoritele Sisemine motivatsioon ja tajutud õpetamisoskused ning Väline motivatsioon ja töö sobivus eraeluga oluliselt kõrgemad hinnangud kui õpetajakoolituse praktikandid. Mõlemad grupid olid kõige kõrgema hinnangu andnud faktorile Sisemine motivatsioon ja tajutud õpetamisoskused ning kõige madalama faktorile Oluliste inimeste mõju. Lisaks andsid kutseaastal olevad õpetajad faktorile Rahulolu kutsevalikuga oluliselt kõrgema hinnangu kui õpetajakoolituse praktikandid. Kahe grupi vahel ilmnesid erinevused ka kutsevalikuga rahulolu ja õpetajatööst ettekujutuse alaploki põhitegurites.
\end{abstract}

Võtmesõnad: õpetajate kutsevalik, motivatsioonitegurid, FIT-Choice, kutseaasta ja õpetajakoolituse praktika, põhjuslik-võrdlev uurimus

Haridusteaduste instituut, sotsiaal- ja haridusteaduskond, Tartu Ülikool, Salme 1a, 50103

Tartu, olivia.voltri@ut.ee 


\section{Sissejuhatus}

Viimastel aastatel on mitmed teadlased tundnud huvi ópetajate kutsevalikut mõjutavate motivatsioonitegurite uurimise vastu, sest $\operatorname{OECD}(2005,2011)$ andmetel on uurimusse kaasatud riikides probleeme õpetajaskonna vananemise ja uute kvalifitseeritud õpetajate kooli tulemisega või õpetajaametile truuks jäämisega. Kõrvutades õpetajaskonna ealist struktuuri teiste riikide omaga, ilmneb, et Eesti ópetaja on keskmisest vanem, näiteks Leedu ja Norra kõrval on Eesti õpetajad ühed eakamad (Eesti õpetajahariduse strateegia, 2008; Loogma, Ruus, Talts, \& Poom-Valickis, 2009). Samuti võib esile tõsta õpetajakutse vähest avalikku tunnustamist Eesti ühiskonnas ja meedias ning väikest töötasu, mis ei ole ühiskonna arengu seisukohalt vastavuses selle ameti tähtsusega - kõige selle tõttu on õpetaja elukutsel omakorda halb maine (Eesti õpetajahariduse strateegia, 2008). Viimase kümnendi statistika näitab, et aina vähem noori valib õpetajakutse (Ots, Vaher, Selliov, \& Laanoja, 2008), ning uurimuste järgi on õpetaja elukutse valik noorte hulgas viimaste eelistuste seas (Krips, Taimalu, Luik, \& Kukemelk, 2009). Kuigi õpetajakoolituse lõpetanute üldine hulk on sellisel tasemel, mis võiks katta lasteaedade ja koolide vajadused, läheb esmaõppe lõpetanud noortest oma erialal tööle tegelikult vaid kolmandik (Ots et al., 2008). 2013. aasta jaanuaris arutati Riigikogus õpetajahariduse hetkeseisu, probleeme ja ootusi kui riiklikult olulist küsimust.

Nende probleemide ja õpetajaharidusele riiklikult seatud eesmärkide valguses on oluline uurida õpetajaks õppivate üliõpilaste ja kutseaastal olevate õpetajate kutsevalikut mõjutavaid motivatsioonitegureid, et saada informatsiooni, mis põhjustel tulevad noored õpetajaks õppima. Õpetajakoolituse üliõpilaste ja algajate õpetajate kutsevalikut mõjutavate motivatsioonitegurite teadmine annab võimaluse õpetajakoolitust paremini korraldada ja õppekavu arendada, värvata õpetajaid ning teha riigi tasandil õpetajakoolitusega seotud olulisi otsuseid (Lin, Shi, Wang, Zhang, \& Hui, 2012; Watt \& Richardson, 2007).

\section{Teoreetiline raamistik}

Õpetajate kutsevalikut mõjutavatest motivatsiooniteguritest arusaamiseks on vaja kõigepealt avada motivatsiooni mõiste. Mõistel motivatsioon puudub konkreetne ja ühene tähendus (Krull, 2000). Motivatsiooni määratletakse peamiselt hüpoteetilise konstruktsioonina ning mõistetakse selle all inimest tegutsema panevat ja tema tegemisi suunavat jõudu (Elliot \& Zahn, 2008). Eesti keele seletava sõnaraamatu (2009) järgi on motivatsioon motiivide kogum, mis inimest tegutsema ajendab, motiiv ise aga ajend või põhjus. Seega võib 
öelda, et eesti keeles on motiiv kitsam mõiste ja motivatsioon laiem. Õpetaja kutsevaliku motivatsiooni käsitleva ingliskeelse kirjanduse põhjal on aga sõnu motivatsioon ja motiiv tihtipeale raske eristada, sest sõna motivation kasutatakse üldjuhul sõna motive sünonüümina (Fokkens-Bruinsma \& Canrinus, 2012; Klassen, Al-Dhafri, Hannok, \& Betts, 2011; Richardson \& Watt, 2006; Sinclair, 2008a; Watt \& Richardson, 2007). Lisaks räägitakse teemakohases ingliskeelses kirjanduses motiivide kõrval õpetajakutse valikut mõjutavatest motiveerivatest teguritest (factors influencing teaching choice) (Kilinç, Watt, \& Richardson, 2012). Eeltoodut arvesse võttes kasutatakse käesolevas töös sõnaühendit õpetajate kutsevalikut mõjutavad motivatsioonitegurid, sest see avab autorite hinnangul piisavalt laialt uuritava temaatika, hõlmates nii motiive, ettekujutust õpetajatööst kui ka rahulolu kutsevalikuga - need kokku moodustavadki õpetaja kutsevalikut mõjutavad motivatsioonitegurid.

Motivatsiooni puhul eristatakse sisemist ja välist motivatsiooni. Sisemist motivatsiooni määratletakse kui inimese tahet tegutseda omaenda sisemisest huvist ehk tegutsetaksegi tegevuse enda pärast, sest tegevus ise pakub rahuldust. Väline motivatsioon viitab aga inimese soovile tegutseda lähtuvalt teo tagajärjest, mis võib olla positiivne (nt kiitus) või negatiivne (nt halb hinne) (Ryan \& Deci, 2000; Woolfolk, 2010).

Õpetajate kutsevalikut mõjutavaid motivatsioonitegureid on uurinud paljud teadlased (Gao \& Trent, 2009; Jarvis \& Woodrow, 2005; Klassen et al., 2011; Moran, Kilpatrick, Abbott, Dallat, \& McClune, 2001; Roness \& Smith, 2010; Sinclair, 2008a) eri riikides (Austraalia, Norra, Inglismaa, Kanada, Omaan, Hongkong, Iirimaa), kuid mõnel uurimusel jääb vajaka heast teoreetilisest raamistikust (Watt et al., 2012). Richardson ja Watt (2006) võtsid oma õpetajate kutsevalikut mõjutavate motivatsioonitegurite skaala väljatöötamisel aluseks eduootuse ja eesmärgi väärtuse kombinatsiooni teooria (expectancy-value theory). Selle teooria pooldajad arvavad, et peamised motivatsioonitegurid akadeemiliste valikute ja käitumise puhul on eduootus ja saavutatava tulemuse väärtuslikkus (Watt \& Richardson, 2007). Eduootuse ja eesmärgi väärtuse kombinatsiooni teooria raames mõistetakse, et inimese motivatsiooni määrab kindlaks see, kuivõrd suur on ta tajutud eduootus ja kuivõrd oluline on tema jaoks saavutatav eesmärk (nt „Ma usun, et ma suudan seda teha, ja see eesmärk on mulle oluline" = motivatsioon) (Atkinson, 1957; Eccles et al., 1983, viidatud Wigfield, Eccles, 2000 j; Fishbein \& Ajzen, 1975; Tollefson, 2000). Lisaks seostatakse eduootuse ja eesmärgi väärtuse kombinatsiooni teooriat enesetõhususe teooriaga (Bandura, 1998), täpsemalt enesetõhususe ootustega (Eccles \& Wigfield, 2002). Eduootuse ja eesmärgi väärtuse kombinatsiooni teooria puhul eristatakse nelja eesmärgi olulisuse komponenti (Wigfield, 1994): 

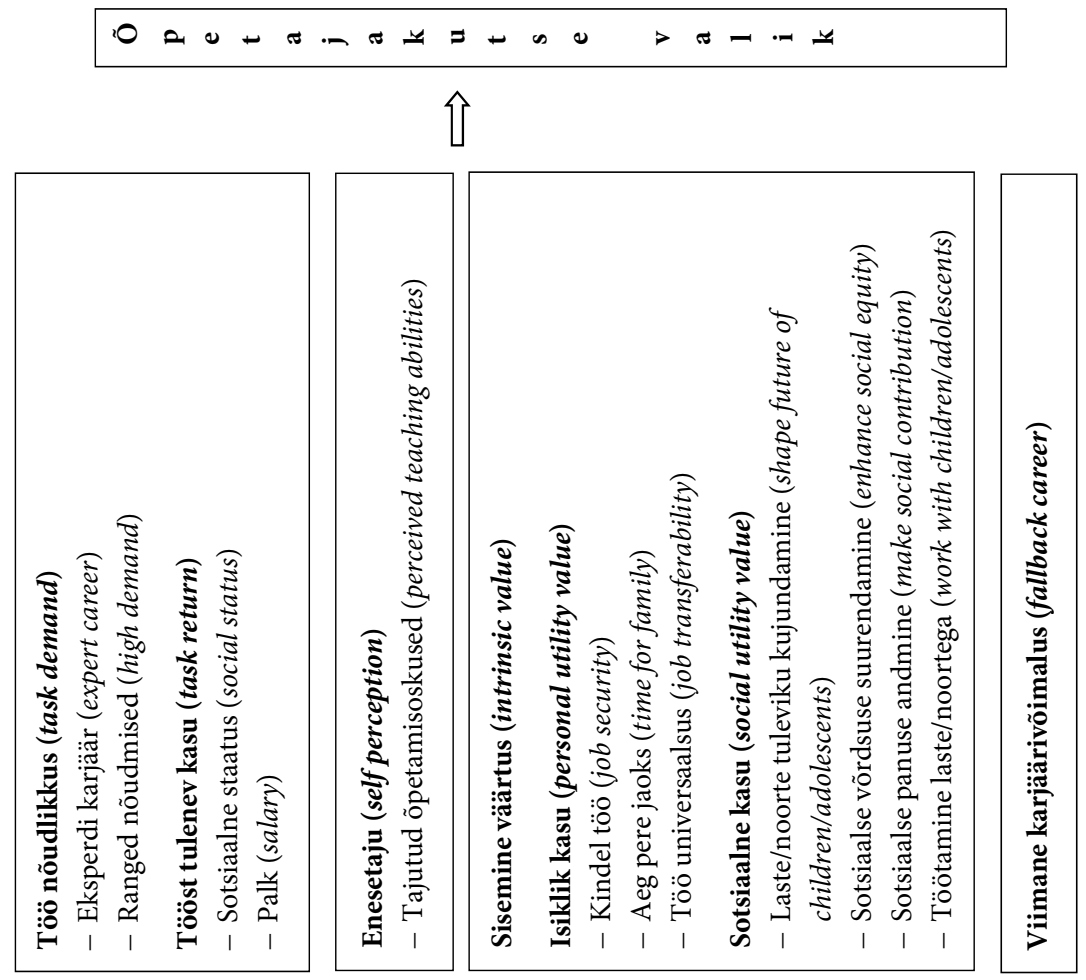

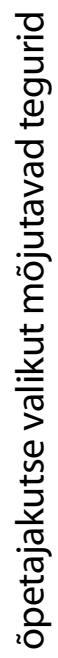

î

蒫

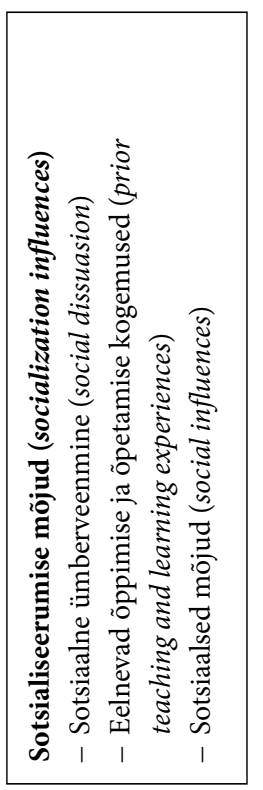

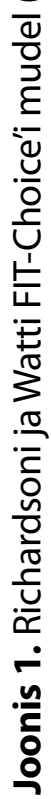


1) saavutuse komponent - eesmärgi saavutamine on inimesele isiklikult oluline, on seotud tema identiteediga (nt „Mulle on oluline olla matemaatikas edukas");

2) sisemise väärtuse komponent - eesmärgi saavutamine pakub inimesele sisemist rahulolu ja naudingut, on seotud sisemise motivatsiooniga (nt „Mulle meeldivad matemaatikaülesanded”);

3) kasulikkuse komponent - mis kasu saab inimene eesmärgi saavutamisest, on seotud välise motivatsiooniga (nt „Võrreldes teiste ainetega on matemaatika õppimine mulle kasulik");

4) maksumuse komponent - inimene on valiku ees ja peab vastama küsimusele, kas selle ülesande sooritus tasub talle end ära (nt „Kas matemaatika õppimine tasub end ära?").

Eduootus ja eesmärgi olulisus mõjutavad ülesande valikut, sooritust ja püsivust (Eccles \& Wigfield, 2002). Analüüsinud eelnevaid käsitlusi, uurinud põhjalikult eduootuse ja eesmärgi väärtuse kombinatsiooni teooriat ning sobitades seda õpetajate kutsevalikut mõjutavate motivatsioonitegurite kontekstiga, koostasid Richardson ja Watt 2006. aastal õpetaja kutsevalikut mõjutavate tegurite mudeli (Factors Influencing Teaching Choice, lühend FIT-Choice) (vt joonis 1). FIT-Choice’i mudeli alusel töötasid nad välja õpetaja kutsevalikut mõjutavate tegurite skaala (edaspidi: FIT-Choice'i skaala) (Watt \& Richardson, 2007), mis on praeguseks kasutusel juba paljudes riikides (nt Austraalias, USAs, Hiinas, Saksamaal, Šveitsis, Hollandis, Türgis) ning võetud ka käesoleva uurimuse aluseks.

\section{Õpetajate kutsevalikut mõjutavate motivatsioonitegurite uurimused}

Uurimused on näidanud, et õpetajate kutsevalikut mõjutavad motivatsioonitegurid varieeruvad, hõlmates nii sisemisi, väliseid kui ka altruistlikke motivatsioonitegureid (Marston, 2010; Sinclair, 2008b; Watt \& Richardson, 2007, 2008). Teadlased on viidanud ka asjaolule, et noore inimese valikut saada õpetajaks mõjutab pigem mitu tegurit kui üks (Richardson \& Watt, 2006; Sinclair, 2008a).

Richardson ja Watt (2006) tegid FIT-Choice’i skaala alusel Austraalia 1653 õpetajakoolituse üliõpilase seas uuringu, millest selgus, et õpetajate kutsevalikut mõjutavatest motivatsiooniteguritest oli kõige kõrgemalt hinnatud sisemisi motivatsioonitegureid, tajutud õpetamisoskusi ja altruistlike väärtustega seotud tegureid (nt laste ja noorte tuleviku kujundamine, tahe töötada laste ja noortega ning tahe panustada ühiskonda). Kõige vähem olid üliõpilased välja toonud õpetajakutse valikut kui viimast karjäärivõimalust (fallback career) ning samuti perekonna, sõprade ja töökaaslaste mõju kutsevalikul. Kuna FIT-Choice’i skaala puhul hindavad üliõpilased ka oma 
ettekujutust õpetajatööst, siis pidasid vastajad kõige tähtsamaks tööga seotud nõudlikkuse tegureid (suur töökoormus ja emotsionaalne pinge) ja õpetajatöö suuri nõudmisi oskustele ning erialastele ja tehnilistele teadmistele. Samas tajusid õpetajakoolituse üliõpilased, et õpetaja elukutse on madala sotsiaalse staatusega ja õpetajad saavad väikest palka. Üllatuslikult kõrgelt hinnati rahulolu õpetajakutse valikuga (seitsmepalliskaalal oli keskmine kuue lähedal).

Peale Watti ja Richardsoni on Austraalias õpetajate kutsevalikut mõjutavaid motivatsioonitegureid uurinud ka Sinclair (2008a), kes kasutas selleks nii avatud küsimustega kui ka Likert-skaala tüüpi küsimustikku. Uurimusest selgus, et peamisteks mõjuteguriteks õpetajakutse valikul peeti töötamist lastega, võimalust end intellektuaalselt proovile panna ja usku enda kui õpetaja võimetesse. Välistest motivatsiooniteguritest toodi kõige sagedamini esile õpetajatöö iseloomu, töötingimusi ning eraeluga sobivust.

Hollandlased Fokkens-Bruinsma ja Canrinus (2012) korraldasid adapteeritud FIT-Choice’i skaala alusel uuringu 151 õpetajakoolituse üliõpilase seas ning jõudsid sarnaste uurimistulemusteni kui Watt ja Richardson (2007). Hollandi üliõpilased hindasid motivatsiooniteguritest kõige kõrgemalt tajutud õpetamisoskust. Sotsiaalsed mõjutused (pere, sõbrad ja töökaaslased), aeg pere jaoks, eelnev õpetamis- ja õppimiskogemus ning tahe suurendada ühiskonnas võrdsust olid tähtsuselt järgmistel kohtadel. Õpetajatööst ettekujutuse alaplokis oli kõige kõrgemalt hinnatud õpetajatöö nõudlikkust ja madalamalt õpetajatöö tasu ja staatust. Rahulolu kutsevalikuga oli üks kõrgeimalt hinnatud tegureid. Sarnastele tulemustele nagu Watt ja Richardson (2007) ning FokkensBruinsma ja Canrinus (2012) on jõudnud mitmed teisedki uurijad (Köning \& Rothland, 2012; Lin et al., 2012) nii Euroopas, USAs kui ka Aasias.

Praeguseks on läbi viidud ka mitu rahvusvahelist võrdlevat uuringut (Lin et al., 2012; Watt et al., 2012), mis võimaldasid hinnata FIT-Choice'i skaala sobivust erinevatesse kultuuridesse ja leida, millised erinevused ilmnevad selle kasutamisel. Võrreldes nelja riigi (Austraalia, USA, Saksamaa, Norra) õpetajakoolituse üliõpilaste kutsevalikut mõjutavaid motivatsioonitegureid, ilmnes, et eri riikide üliõpilaste hinnangud olid sarnased. Kõik nimetatud riikide üliõpilased hindasid ühtviisi kõrgelt viit motivatsioonitegurit: sisemist motivatsiooni, õpetamisoskuste tajumist, soovi panustada ühiskonda, võimalust töötada laste/noortega ning varasemaid positiivseid õppimis- ja õpetamiskogemusi. Personaalse kasulikkusega seotud väärtusi, nagu töö turvalisus, aeg perekonna jaoks ning soov suurendada sotsiaalset võrdsust, hinnati nelja riigi lõikes madalamalt. Kõige madalamalt (ainsana alla skaala keskmise) hinnati sõprade, pere ja töökaaslaste mõju õpetajakutse valikule (Watt et al., 2012). Erinevaid uurimistulemusi kokku võttes võib öelda, et õpetajakoolituse üliõpilaste puhul saavad õpetajakutse valikul määravaks pigem sisemised kui välised motivatsioonitegurid. 
Mõned teadlased on uurinud õpetajakoolituse üliõpilaste kutsevalikut mõjutavaid motivatsioonitegureid ka erinevate erialade ja soo alusel. Kilinç jt (2012) võrdlesid reaalainete (matemaatika, keemia jt; valim 481) ja humanitaarainete (keeleõpetajad, ajaloolased jt, sealhulgas 16\% lasteaia- ja klassiõpetajaid jt; valim 1094) õppekavadel õppivaid õpetajakoolituse üliõpilasi. Reaalainete õpetajakoolituse üliõpilased hindasid enamikku kutsevalikut mõjutavaid motivatsioonitegureid oluliselt madalamalt kui humanitaarainete õppekavadel õppivad üliõpilased. Ainult tegurit viimane karjäärivõimalus hindasid reaalainete üliõpilased kõrgemalt, kuid töö universaalsuse puhul olulist erinevust gruppide vahel ei esinenud. Humanitaarainete õppekavadel õppijad hindasid märgatavalt kõrgemalt rahulolu erialavalikuga ning enamikku teisi õpetajatöö ettekujutusega seotud tegureid. Seevastu nais- ja meesüliõpilaste võrdlusest ilmnes, et õpetajakoolituse naistudengid hindasid keskmiselt kõrgemalt suuremat osa motivatsioonitegureid, välja arvatud tegurit viimane karjäärivõimalus. Võrdluseks: Bruinsma ja Janseni (2010) läbi viidud uuringus 198 õpetajakoolituse üliõpilasega selgus, et naistudengid hindasid sisemisi kutsevalikut mõjutavaid motivatsioonitegureid kõrgemalt kui meestudengid.

Uurimused on näidanud, et õpetaja kutsevalikut mõjutavatel motivatsiooniteguritel on seos sellega, kui rahul on ta õpetajakarjäriga ning kas ta plaanib jääda truuks valitud erialale (Watt \& Richardson, 2008). Seega on oluline välja selgitada nii õpetajakoolituse üliõpilaste kui ka kutseaastal olevate õpetajate kutsevalikut mõjutavad motivatsioonitegurid: see võib aidata õpetajakoolituse korraldajatel paremini mõista, kuidas motiveerida üliõpilasi õpetajaks tööle minema ning algajaid õpetajaid sellele elukutsele truuks jääma.

\section{Eesmärk ja uurimisküsimused}

Uurimuse eesmärk on võrrelda õpetajakoolituse praktikantide ja kutseaastal olevate õpetajate kutsevalikut mõjutavaid motivatsioonitegureid. Uurimistöös otsitakse vastuseid järgmistele küsimustele:

1) milliseid erinevusi kutsevalikut mõjutavate motivatsioonitegurite faktorstruktuurides leidub õpetajakoolituse praktikantide ja kutseaastal olevate õpetajate vahel?

2) kuidas erinevad õpetajakoolituse praktikandid ja kutseaastal olevad õpetajad kutsevalikut mõjutavate motivatsioonitegurite poolest?

3) millised kutsevalikut mõjutavad motivatsioonitegurid on olulisemad õpetajakoolituse praktikantide ja millised kutseaastal olevate õpetajate jaoks? 


\section{Metoodika}

Uuringus kasutati põhjuslikku-võrdlevat uurimisstrateegiat, sest võrreldi kahte gruppi ning eeldati, et erinevused on gruppide vahel olemas (st neid erinevusi ei kutsuta esile nagu eksperimendis). Uurimisstrateegia alusel püüti moodustada võimalikult homogeensed grupid ning valida sobivad võrdlustestid.

\section{Valim}

Valimi moodustas 396 vastajat, kellest 189 (48\%) olid õpetajakoolituse praktikandid ja 207 (52\%) kutseaastal olevad õpetajad. Neist 252 (64\%) olid Tartu Ülikoolist ja 143 (36\%) Tallinna Ülikoolist. Üks vastaja oli ülikooli märkimata jätnud. Valimi moodustamisel võeti aluseks põhimõte, et see peab sisaldama erinevate erialade õpetajakoolituse praktikante ja kutseaastal olevaid oppetajaid.

Valimi jaotusest soo ja eriala alusel annab ülevaate tabel 1. Valim koosnes 363 naisest ja 32 mehest ning üks vastaja oli oma soo märkimata jätnud. Valimist moodustasid 33\% lasteaiaõpetajad, 16\% klassiõpetajad, 48\% aineõpetajad ning 3\% muud spetsialistid (eripedagoogid, sotsiaalpedagoogid, logopeedid). Üks vastaja ei olnud oma eriala märkinud.

Tabel 1. Ülevaade valimist soo ja eriala alusel

\begin{tabular}{l|c|c|c|c|c|c}
\hline & \multicolumn{2}{|c|}{$\begin{array}{c}\text { Opetajakoolituse } \\
\text { praktikandid }\end{array}$} & \multicolumn{2}{|c|}{$\begin{array}{c}\text { Kutseaastal } \\
\text { olevad õpetajad }\end{array}$} & \multicolumn{2}{|c}{ Kokku } \\
\hline Mehed & 26 & $14 \%$ & 6 & $3 \%$ & 32 & $8 \%$ \\
\hline Naised & 162 & $86 \%$ & 201 & $97 \%$ & 363 & $92 \%$ \\
\hline Lasteaiaõpetajad & 44 & $23 \%$ & 87 & $42 \%$ & 131 & $33 \%$ \\
\hline Klassiõpetajad & 23 & $12 \%$ & 39 & $19 \%$ & 62 & $16 \%$ \\
\hline Aineõpetajad & 122 & $65 \%$ & 69 & $34 \%$ & 191 & $48 \%$ \\
\hline Loodusainete õpetajad & 6 & $3 \%$ & 18 & $9 \%$ & 24 & $6 \%$ \\
\hline Reaalainete õpetajad & 11 & $6 \%$ & 2 & $1 \%$ & 13 & $3 \%$ \\
\hline Humanitaarainete õpetajad & 83 & $44 \%$ & 41 & $20 \%$ & 124 & $31 \%$ \\
\hline Oskusainete õpetajad & 22 & $12 \%$ & 8 & $4 \%$ & 30 & $8 \%$ \\
\hline $\begin{array}{l}\text { Muud spetsialistid (eri- ja } \\
\text { sotsiaalpedagoogid, logo- } \\
\text { peedid) }\end{array}$ & 0 & $0 \%$ & 11 & $5 \%$ & 11 & $3 \%$ \\
\hline
\end{tabular}

Vastajate keskmine vanus oli 25,9 aastat (SD $=5,7)$, kusjuures õpetajakoolituse üliõpilaste keskmine vanus oli $24,9(S D=5,1)$ ja kutseaastal olevate õpetajate keskmine vanus oli $26,9(S D=6,1)$. 


\section{Mõõtevahend}

Andmeid koguti ankeediga, mis baseerus Watti ja Richardsoni (2007) välja töötatud skaalal õpetajate kutsevalikut mõjutavate motivatsioonitegurite kohta, teisisõnu FIT-Choice'i skaalal. FIT-Choice'i skaala koosneb kolmest osast, sisaldades väiteid, mis on seotud õpetajakutse valiku motiividega, ettekujutusega õpetajatööst ja rahuloluga kutsevaliku üle. Originaalvariant on ingliskeelne, koosneb 57 väitest, millele antakse hinnangud seitsmepalliskaalal ( 1 - pole üldse oluline, 7 - väga oluline) ning mis töötati välja Austraalia õpetajakoolituse üliõpilaste jaoks. Ankeedi väljatöötamisel kontrollisid Watt ja Richardson (2007) nii skaala sisereliaablust (vahemikus 0,62-0,92) kui ka valiidsust. Viimast kontrolliti Watti ja Richardsoni kinnitava faktoranalüüsiga. See näitas mudeli vastavust teooriaga. Mudeli psühhomeetrilised parameetrid olid järgmised: RMSEA (root mean square error of approximation) $=0,049$; NFI (normed fit index) $=0,922$; NNFI (non-normed fit index $)=0,952$; GFI (goodness of fit index) $=0,824$; AGFI (adjusted goodness of fit index) $=0,788$ (Watt $\&$ Richardson, 2007). FIT-Choice'i skaala adapteeritud variante on kasutatud praeguseks erinevates kultuurides ning tulemused on näidanud ankeedi head valiidsust ja reliaablust (Berger \& D’Ascoli, 2012; Köning \& Rothland, 2012; Jugović, Marušić, Ivanec, \& Vidović, 2012; Kilinç et al., 2012).

Artikli autorid jätsid Eesti tarvis kohandatud FIT-Choice'i variandist mitmed väited erinevatel põhjustel välja, lisaks tegid nad originaalskaalaga võrreldes muidki muudatusi. Esmalt tõlkis üks uurijatest originaalskaala eesti keelde ning seejärel hindasid kaks ülejäänud uurijat eesti- ja ingliskeelsete väidete vastavust. Lõpuks arutleti töögrupis põhjalikult väidete arusaadavuse ning Eesti konteksti sobivuse üle. Enne pilootuuringut jäeti välja 3 väidet, mis olid seotud töö universaalsusega (job transferability), 3 väidet, mis olid seotud originaalskaala faktoriga Sotsiaalne ümberveenmine (social dissuasion), ning 3 väidet (nt „Osaajaline töö jätab pere jaoks rohkem aega”) originaalskaala erinevatest faktoritest, sest ükski neist ei sobinud Eesti konteksti. Võrreldes originaalskaalaga loobuti veel 8 väitest (kuulusid erinevatesse faktoritesse), sest tõlkides muutusid need teiste väidetega väga sarnaseks. Väitest „Minu töökaaslased arvavad, et peaksin hakkama õpetajaks" loobuti seetõttu, et küsitleti inimesi, kellel polnud üldjuhul varasemat töökogemust ja kes ei saanud seetõttu sellele väitele reageerida. Lisaks tehti muudatus skaala ulatuses. FIT-Choice’i skaala oli üks osa suuremast uurimusest ning kuna teisi skaalasid hinnati seal viiepallisüsteemis, siis muudeti ka Eesti jaoks kohandatud skaala viiepalliliseks ( 1 - pole üldse oluline, 5 - väga oluline). Originaalskaala teine ja kolmas osa koosnesid küsimustest, mis muudeti skaalat Eesti konteksti kohandades väideteks.

Ankeeti katsetati 2010. aasta kevadel 22 õpetajakoolituse üliõpilase ja 18 kutseaastal oleva õpetaja seas. Vastajate kommentaaride alusel parandati 
ankeedi sõnastust ning jäeti välja väide „Mulle meeldib töötamine laste/ noortega", sest pilootuuringus osalenud pidasid seda samaväärseks väitega „Ma tahan aidata lastel ja noortel õppida”.

Eelloetletud muudatuste tulemusena kasutati käesolevas uurimuses FITChoice'i skaalast 38 väidet, mis jaotati kahte ossa: esimene osa hõlmas õpetajakutse valiku motiive (26 väidet) ning teine osa ettekujutust õpetajatööst ja rahulolu kutsevalikuga (12 väidet). Ankeet sisaldas ka taustaküsimusi, milles taheti teada vastaja sugu, vanust ja õpitavat või omandatud eriala.

\section{Protseduur}

Uuring viidi läbi 2010. ja 2012. aastal. Õpetajakoolituse praktikante küsitleti pedagoogilise põhipraktika alguses ning kutseaastal olevaid õpetajaid kutseaasta alguses. Uuringus osalejad täitsid ankeedi uuringut tutvustavas seminaris paberil, seminarist puudujatele saadeti uuringut tutvustav tekst e-postiga ja nemad täitsid ankeedi elektroonilise vormi.

Andmete analüüsimiseks kasutati tarkvara SPSS PASW Statistics 20. Õpetajate kutsevalikut mõjutavate motivatsioonitegurite faktormudeli väljaselgitamiseks tehti peakomponentide meetodi (principal components method) abil uuriv faktoranalüüs ning faktorite paremaks tõlgendamiseks kasutati ortogonaalset Varimaxi pööramise meetodit. Uuriva faktoranalüüsi kasutamine oli tingitud asjaolust, et tegemist oli FIT-Choice'i skaala lühendatud variandiga. Watti ja Richardsoni (2007) FIT-Choice'i skaala faktorstruktuuriga võrreldes ei moodustunud kasutatud faktoranalüüsi tulemusena kõik faktorid ja mõnesse faktorisse koondus vaid 1-2 väidet. Seetõttu polnud teada, milliseks kujuneb modifitseeritud faktorstruktuur.

Kuna FIT-Choice'i skaala õpetajakutse valiku motiivide osa (26 väidet) sisaldas kahte negatiivse orientatsiooniga väidet („Olin oma erialavalikus ebakindel”; „Ma ei pääsenud õppima seda eriala, mis oli mu esimene eelistus"), siis pöörati nende väidete skaala enne faktoranalüüsi ümber, et neid saaks tõlgendada sama moodi kui teisi väiteid.

Faktoritesse koondunud alaskaalade sisereliaabluse arvutamiseks kasutati Cronbachi alfa näitajat.

Richardson ja Watt (2006) leidsid summaarsed faktorskoorid faktorisse kuuluvate üksikväidete aritmeetiliste keskmiste põhjal. Ka käesolevas uurimuses arvutati üksikväidete aritmeetiliste keskmiste alusel summaarsed faktorskoorid, mida edaspidi nimetatakse lihtsalt faktoriteks. Õpetajakoolituse praktikantide ja kutseaastal olevate õpetajate kutsevalikut mõjutanud motivatsioonitegurite faktorite võrdlemiseks kasutati sõltumatute valimite t-testi ning kõrgeimalt hinnatavate faktorite väljaselgitamiseks gruppide arvestuses sõltuvate valimite $\mathrm{t}$-testi. 


\section{Tulemused}

Kõigepealt leiti faktorstruktuurid kahe valimi puhul eraldi (õpetajakoolituse praktikandid ja kutseaastal olevad õpetajad), et teada saada, kas faktorstruktuurid on sarnased, mis annaks õiguse kahte gruppi nende alusel võrrelda.

Õpetajakoolituse praktikantide grupi õpetajakutse valiku motiivide puhul (26 väidet) tekkis pärast kolme väite („Olin oma erialavalikus ebakindel”; „Ma ei pääsenud õppima seda eriala, mis oli mu esimene eelistus”; „Ma olen alati tahtnud olla õpetaja”) eemaldamist madalate kommunaliteetide tõttu viiefaktoriline struktuur (mudeli kirjeldatavus 60,7\%; kõikide väidete kommunaliteedid üle 0,4) (tabel 2). Ka kutseaastal olevate õpetajate grupi õpetajakutse valiku motiivide skaala puhul (26 väidet) tuli eemaldada needsamad kolm väidet. Selle tulemusena tekkis samuti viiefaktoriline struktuur, mis sarnanes võrreldava grupi omaga (mudeli summaarne kirjeldatavus $58,3 \%$; kõikide väidete kommunaliteedid üle 0,4 ). Ainus erinevus seisnes ühe väite paigutumises erinevatesse faktoritesse (tabel 2).

Tabel 2. Õpetajakoolituse praktikantide ja kutseaastal olevate õpetajate kutsevaliku motiivide faktorstruktuuri võrdlus

\begin{tabular}{l|c|c}
\hline Faktorid ja väited & $\begin{array}{c}\text { Õpetaja- } \\
\text { koolituse } \\
\text { praktikandid }\end{array}$ & $\begin{array}{c}\text { Kutseaastal } \\
\text { olevad } \\
\text { opetajad }\end{array}$ \\
\hline 1. Sisemine motivatsioon ja tajutud õpetamisoskused & + & + \\
\hline Mulle meeldib õpetamine & + & + \\
\hline Ma olen huvitatud õpetamisest & + & + \\
\hline Mul on head õpetamisoskused & + & + \\
\hline Mul on hea õpetaja omadused & + & + \\
\hline Õpetaja elukutse sobib minu võimetega & + \\
\hline $\begin{array}{l}\text { Ma tahan teha tööd, kus saab laste/noortega } \\
\text { töötada }\end{array}$ & + & + \\
\hline 2. Soov noorte jaoks kasulik olla ja ühiskonda teenida & + & + \\
\hline $\begin{array}{l}\text { Õpetajatöö võimaldab mul tõsta kehvemast } \\
\text { keskkonnast pärit noorte edasipüüdlikkust }\end{array}$ & + & + \\
\hline $\begin{array}{l}\text { Õpetamine võimaldab mul head teha kehvematest } \\
\text { tingimustest tulnud noortele }\end{array}$ & + & + \\
\hline $\begin{array}{l}\text { Õpetamine võimaldab mul kujundada laste/noorte } \\
\text { väärtusi }\end{array}$ & - & + \\
\hline $\begin{array}{l}\text { Õpetajatöö võimaldab mul mõjutada järgmist } \\
\text { põlvkonda }\end{array}$ & + & + \\
\hline Ma tahan aidata lastel/noortel õppida & + & + \\
\hline Õpetajatöö võimaldab mul ühiskonda teenida & + & + \\
\hline
\end{tabular}




\begin{tabular}{l|c|c}
\hline Faktorid ja väited & $\begin{array}{c}\text { Õpetaja- } \\
\text { koolituse } \\
\text { praktikandid }\end{array}$ & $\begin{array}{c}\text { Kutseaastal } \\
\text { olevad } \\
\text { öpetajad }\end{array}$ \\
\hline 3. Väline motivatsioon ja töö sobivus eraeluga & + & + \\
\hline Õpetaja tööaeg sobib pereeluga & + & + \\
\hline Õpetajana on mul lühike tööpäev & + & + \\
\hline Koolivaheajad sobivad kokku pereeluga & + & + \\
\hline Õpetajatöö pakub stabiilset sissetulekut & + & + \\
\hline $\begin{array}{l}\text { Õpetaja elukutse pakub kindlat töökohta } \\
\text { (õpetajatel on alati tööd) }\end{array}$ & + & + \\
\hline $\begin{array}{l}\text { Õpetajana on mul pikad koolivaheajad / pikk } \\
\text { puhkus }\end{array}$ & + & + \\
\hline 4. Varasemad õppimiskogemused & + & + \\
\hline Mul on olnud head õpetajad eeskujuks & + & + \\
\hline Mul on olnud inspireerivad õpetajad & + & + \\
\hline Mul on olnud positiivsed õppimiskogemused & + & + \\
\hline $\begin{array}{l}\text { 5. Oluliste inimeste mõju } \\
\text { Mu sõbrad arvavad, et ma peaksin saama õpetajaks }\end{array}$ & + & + \\
\hline $\begin{array}{l}\text { Minu perekond arvab, et ma peaksin saama } \\
\text { õpetajaks }\end{array}$ & + Õpetajatöö võimaldab mul ühiskonda teenida & + \\
\hline
\end{tabular}

Märkus. + väide faktoris olemas; - väide faktoris puudub.

Koguvalimi (õpetajakoolituse üliõpilased ja kutseaastal olevad õpetajad, valim 396) õpetajakutse valiku motiivide faktoranalüüsi puhul võeti alguses kasutusele kõik 26 väidet, kuid analüüsi käigus eemaldati väidete madalate kommunaliteetide tõttu kolm väidet („Olin oma erialavalikus ebakindel”; „Ma ei pääsenud õppima seda eriala, mis oli mu esimene eelistus”; „Ma olen alati tahtnud olla õpetaja"). Lõplikku faktoranalüüsi jäi 23 väidet. Seega, kasutades uurivat faktoranalüüsi peakomponentide meetodit ortogonaalse Varimaxi pööramisega, tekkis õpetajakutse valiku motiivide puhul viiefaktoriline struktuur (tabel 3). Viie faktori summaarne kirjeldatavus oli 59,0\% ning kõikide väidete kommunaliteedid olid vähemalt väärtusega 0,4 . 
Tabel 3. Õpetajakutse valiku motiivide faktorstruktuur ja faktorite reliaablused koguvalimil

\begin{tabular}{|c|c|c|c|c|c|}
\hline \multirow{2}{*}{ Faktorid ja väited } & \multicolumn{5}{|c|}{ Faktorlaadungi väärtus } \\
\hline & 1 & 2 & 3 & 4 & 5 \\
\hline \multicolumn{6}{|l|}{$\begin{array}{l}\text { 1. Sisemine motivatsioon ja tajutud õpetamis- } \\
\text { oskused }\end{array}$} \\
\hline Mulle meeldib õpetamine & 0,80 & & & & \\
\hline Ma olen huvitatud õpetamisest & 0,70 & & & & \\
\hline Mul on head õpetamisoskused & 0,68 & & & & \\
\hline Mul on hea õpetaja omadused & 0,65 & & & & \\
\hline Õpetaja elukutse sobib minu võimetega & 0,63 & & & & \\
\hline $\begin{array}{l}\text { Ma tahan teha tööd, kus saab laste/noortega } \\
\text { töötada }\end{array}$ & 0,56 & & & & \\
\hline \multicolumn{6}{|l|}{$\begin{array}{l}\text { 2. Soov noorte jaoks kasulik olla ja ühiskonda } \\
\text { teenida }\end{array}$} \\
\hline $\begin{array}{l}\text { Õpetajatöö võimaldab mul tõsta kehvemast } \\
\text { keskkonnast pärit noorte edasipüüdlikkust }\end{array}$ & & 0,77 & & & \\
\hline $\begin{array}{l}\text { Õpetamine võimaldab mul head teha } \\
\text { kehvematest tingimustest tulnud noortele }\end{array}$ & & 0,76 & & & \\
\hline $\begin{array}{l}\text { Õpetamine võimaldab mul kujundada laste/ } \\
\text { noorte väärtusi }\end{array}$ & & 0,75 & & & \\
\hline $\begin{array}{l}\text { Õpetajatöö võimaldab mul mõjutada järgmist } \\
\text { põlvkonda }\end{array}$ & & 0,69 & & & \\
\hline Ma tahan aidata lastel/noortel õppida & & 0,61 & & & \\
\hline Õpetajatöö võimaldab mul ühiskonda teenida & & 0,55 & & & \\
\hline \multicolumn{6}{|l|}{ 3. Väline motivatsioon ja töö sobivus eraeluga } \\
\hline Õpetaja tööaeg sobib pereeluga & & & 0,77 & & \\
\hline Õpetajana on mul lühike tööpäev & & & 0,73 & & \\
\hline Koolivaheajad sobivad kokku pereeluga & & & 0,72 & & \\
\hline Õpetajatöö pakub stabiilset sissetulekut & & & 0,71 & & \\
\hline $\begin{array}{l}\text { Õpetaja elukutse pakub kindlat töökohta } \\
\text { (õpetajatel on alati tööd) }\end{array}$ & & & 0,62 & & \\
\hline $\begin{array}{l}\text { Õpetajana on mul pikad koolivaheajad / pikk } \\
\text { puhkus }\end{array}$ & & & 0,60 & & \\
\hline \multicolumn{6}{|l|}{ 4. Varasemad õppimiskogemused } \\
\hline Mul on olnud head õpetajad eeskujuks & & & & 0,90 & \\
\hline Mul on olnud inspireerivad õpetajad & & & & 0,88 & \\
\hline Mul on olnud positiivsed õppimiskogemused & & & & 0,77 & \\
\hline
\end{tabular}




\begin{tabular}{l|c|c|c|c|c}
\hline \multirow{2}{*}{ Faktorid ja väited } & \multicolumn{5}{|c}{ Faktorlaadungi väärtus } \\
\cline { 2 - 6 } & $\mathbf{1}$ & $\mathbf{2}$ & $\mathbf{3}$ & $\mathbf{4}$ & $\mathbf{5}$ \\
\hline 5. Oluliste inimeste mõju & & & & & \\
\hline $\begin{array}{l}\text { Mu sõbrad arvavad, et ma peaksin saama } \\
\text { õpetajaks }\end{array}$ & & & & & 0,87 \\
\hline $\begin{array}{l}\text { Minu perekond arvab, et ma peaksin saama } \\
\text { oppetajaks }\end{array}$ & & & & & 0,76 \\
\hline Faktori kirjeldatavus (\%) & 14,21 & 13,74 & 13,33 & 10,49 & 7,25 \\
\hline Cronbachi alfa & 0,80 & 0,80 & 0,79 & 0,84 & 0,80 \\
\hline
\end{tabular}

Motivatsioonitegurite teine osa (ettekujutus õpetajatööst ja rahulolu kutsevalikuga) sisaldas 12 väidet, mille kohta tehti samuti kõigepealt faktoranalüüs, seejuures analüüsiti kahte gruppi (õpetajakoolituse praktikandid ja kutseaastal olevad õpetajad) eraldi. Õpetajakoolituse praktikantide grupis tekkis pärast kolme väite („Ôpetajatel on suur töökoormus”; „Õpetamine on raske töö”; „Õpetajaid peetakse professionaalideks”) eemaldamist madalate kommunaliteetide tõttu kolmefaktoriline struktuur (mudeli summaarne kirjeldatavus 66,5\%; kõikide väidete kommunaliteedid üle 0,4) (tabel 4). Ka kutseaastal olevate õpetajate grupis tekkis pärast kahe väite („Õpetajad vajavad häid erialaseid teadmisi”; „Õpetajatöö on hästi tasustatud”) eemaldamist madalate kommunaliteetide tõttu kolmefaktoriline struktuur (mudeli summaarne kirjeldatavus 58,9\%; kõikide väidete kommunaliteedid üle 0,4) (tabel 4).

Tabel 4. Õpetajakoolituse praktikantide ja kutseaastal olevate õpetajate õpetajatööst ettekujutuse ja kutsevalikuga rahulolu faktorstruktuuri võrdlus

\begin{tabular}{l|c|c}
\hline Faktorid ja väited & $\begin{array}{c}\text { Õpetajakoolituse } \\
\text { praktikandid }\end{array}$ & $\begin{array}{c}\text { Kutseaastal } \\
\text { olevad õpetajad }\end{array}$ \\
\hline $\begin{array}{l}\text { 1. Sotsiaalne staatus ja palk (kutseaastal ole- } \\
\text { vate õpetajate puhul sotsiaalne staatus) }\end{array}$ & + & + \\
\hline $\begin{array}{l}\text { Õpetajad tunnevad end ühiskonna poolt } \\
\text { väärtustatuna }\end{array}$ & + & + \\
\hline $\begin{array}{l}\text { Õpetaja elukutset peetakse kõrge staatusega } \\
\text { ametiks }\end{array}$ & + & + \\
\hline Õpetajatöö on hästi tasustatud & - & + \\
\hline Õpetajaid peetakse professionaalideks & + & + \\
\hline 2. Rahulolu kutsevalikuga & + & + \\
\hline Olen õnnelik oma otsuse üle saada õpetajaks & + & + \\
\hline Ma olen rahul oma valikuga saada õpetajaks & & + \\
\hline
\end{tabular}




\begin{tabular}{l|c|c}
\hline Faktorid ja väited & $\begin{array}{c}\text { Õpetajakoolituse } \\
\text { praktikandid }\end{array}$ & $\begin{array}{c}\text { Kutseaastal } \\
\text { olevad õpetajad }\end{array}$ \\
\hline 3. Suured nõudmised ametioskustele & + & + \\
\hline Õpetajatöö on häid oskusi nõudev & + & + \\
\hline Õpetajatöö on emotsionaalselt nõudlik & + & + \\
\hline Õpetajatel on kõrge moraal & - & - \\
\hline Õpetamine on raske töö & + & + \\
\hline Õpetajad vajavad häid erialaseid teadmisi & - & + \\
\hline Õpetajatel on suur töökoormus & & + \\
\hline
\end{tabular}

Märkus. + väide faktoris olemas; - väide faktoris puudub.

Koguvalimi (õpetajakoolituse praktikandid ja kutseaastal olevad õpetajad, valim 396) faktoranalüüsi võeti alguses kõik 12 väidet, mis olid seotud ettekujutusega õpetajatööst ja rahuloluga kutsevaliku üle. Nendest kaks väidet („Ôpetajatel on suur töökoormus”; „Õpetajad vajavad häid erialaseid teadmisi”) eemaldati väidete madalate kommunaliteetide tõttu. Lõplikku faktoranalüüsi jäi 10 väidet. Seega, kasutades uurivat faktoranalüüsi peakomponentide meetodit ortogonaalse Varimaxi pööramisega, tekkis ettekujutusega õpetajatööst ja rahuloluga kutsevaliku üle seotud väidete puhul kolmefaktoriline struktuur (tabel 5). Mudeli summaarne kirjeldatavus oli 59,6\% ja kõikide väidete kommunaliteedid vähemalt 0,4.

Tabel 5. Õpetajatööst ettekujutuse ja kutsevalikuga rahulolu faktorstruktuur ning faktorite reliaablused koguvalimil

\begin{tabular}{l|c|c|c}
\hline \multirow{2}{*}{ Faktorid ja väited } & \multicolumn{3}{|c}{ Faktorlaadungi väärtus } \\
\cline { 2 - 4 } & $\mathbf{1}$ & $\mathbf{2}$ & $\mathbf{3}$ \\
\hline 1. Sotsiaalne staatus ja palk & & & \\
\hline $\begin{array}{l}\text { Õpetajad tunnevad end ühiskonna poolt } \\
\text { väärtustatuna }\end{array}$ & 0,81 & & \\
\hline $\begin{array}{l}\text { Õpetaja elukutset peetakse kõrge staatusega } \\
\text { ametiks }\end{array}$ & 0,77 & & \\
\hline Õpetajatöö on hästi tasustatud & 0,62 & & \\
\hline Õpetajaid peetakse professionaalideks & 0,6 & & \\
\hline 2. Rahulolu kutsevalikuga & & & \\
\hline Olen õnnelik oma otsuse üle saada õpetajaks & & 0,95 & \\
\hline Ma olen rahul oma valikuga saada õpetajaks & & 0,95 & \\
\hline 3. Suured nõudmised ametioskustele & & & \\
\hline Õpetajatöö on häid oskusi nõudev & & & 0,76 \\
\hline
\end{tabular}




\begin{tabular}{l|c|c|c}
\hline \multirow{2}{*}{ Faktorid ja väited } & \multicolumn{3}{|c}{ Faktorlaadungi väärtus } \\
\cline { 2 - 4 } & $\mathbf{1}$ & $\mathbf{2}$ & $\mathbf{3}$ \\
\hline Õpetajatöö on emotsionaalselt nõudlik & & & 0,73 \\
\hline Õpetajatel on kõrge moraal & & & 0,55 \\
\hline Õpetamine on raske töö & & & 0,52 \\
\hline Faktori kirjeldatavus (\%) & 22,65 & 19,16 & 17,79 \\
\hline Cronbachi alfa & 0,69 & 0,93 & 0,51 \\
\hline
\end{tabular}

Võrreldes õpetajakoolituse praktikantide ja kutseaastal olevate õpetajate kutsevaliku motiive sõltumatute valimite t-testi alusel, ilmnes statistiliselt oluline erinevus kahe faktori ulatuses: Sisemine motivatsioon ja tajutud oppetamisoskused ning Väline motivatsioon ja töö sobivus eraeluga (tabel 6).

Tabel 6. Õpetajakoolituse praktikantide ja kutseaastal olevate õpetajate kutsevaliku motiivide faktoritele antud keskmiste hinnangute võrdlus

\begin{tabular}{|c|c|c|c|c|c|}
\hline \multirow[b]{2}{*}{ Faktorid } & \multicolumn{2}{|c|}{$\begin{array}{c}\text { Õpetajakoolituse } \\
\text { praktikandid }\end{array}$} & \multicolumn{2}{|c|}{$\begin{array}{c}\text { Kutseaastal } \\
\text { olevad õpetajad }\end{array}$} & \multirow[b]{2}{*}{$t$} \\
\hline & $M$ & $S D$ & $M$ & $S D$ & \\
\hline $\begin{array}{l}\text { 1. Sisemine motivatsioon ja } \\
\text { tajutud õpetamisoskused }\end{array}$ & 4 & 0,6 & 4,22 & 0,53 & $3,82^{* *}$ \\
\hline $\begin{array}{l}\text { 2. Soov noorte jaoks kasulik } \\
\text { olla ja ühiskonda teenida }\end{array}$ & 3,86 & 0,7 & 3,92 & 0,67 & 0,94 \\
\hline $\begin{array}{l}\text { 3. Varasemad õppimis- } \\
\text { kogemused }\end{array}$ & 3,72 & 1,06 & 3,77 & 1,01 & 0,48 \\
\hline $\begin{array}{l}\text { 4. Väline motivatsioon ja töö } \\
\text { sobivus eraeluga }\end{array}$ & 2,94 & 0,87 & 3,17 & 0,87 & $2,62^{* *}$ \\
\hline 5. Oluliste inimeste mõju & 2,46 & 1,18 & 2,47 & 1,26 & 0,05 \\
\hline
\end{tabular}

Märkus. ${ }^{* *} p<0,01$.

Õpetajakoolituse praktikantide puhul erines kõige kõrgemalt hinnatud faktor Sisemine motivatsioon ja tajutud ópetamisoskused statistiliselt kõikidest teistest kutsevaliku motiivide faktoritest (erinevus teisel kohal olevast faktorist Soov noorte jaoks kasulik olla ja ühiskonda teenida, $t=3,18, p<0,01$ ). Kõige madalamalt hinnatud faktori Oluliste inimeste mõju ja kõigi teiste faktorite vahel leiti samuti statistiliselt oluline erinevus (erinevus eelviimasel kohal olevast faktorist Väline motivatsioon ja töö sobivus eraeluga, $t=5,44$, $p<0,001)$. Ka kutseaastal olevate õpetajate grupi puhul erines kõige kõrgemalt 
hinnatud faktor Sisemine motivatsioon ja tajutud õpetamisoskused statistiliselt olulisel määral kõikidest teistest kutsevaliku motiivide faktoritest (erinevus teisel kohal olevast faktorist Soov noorte jaoks kasulik olla ja ühiskonda teenida, $t=6,42, p<0,001)$. Kõige madalamalt hinnatud faktori Oluliste inimeste mõju ja kõigi teiste faktorite vahel leiti samuti statistiliselt oluline erinevus (erinevus eelviimasel kohal olevast faktorist Väline motivatsioon ja töö sobivus eraeluga, $t=7,97, p<0,001$ ).

Võrreldes õpetajakoolituse praktikantide ja kutseaastal olevate õpetajate ettekujutust õpetajatööst ja rahulolu kutsevalikuga, ilmnes statistiliselt oluline erinevus ühe faktori osas: Rahulolu kutsevalikuga (tabel 7).

Tabel 7. Õpetajakoolituse praktikantide ja kutseaastal olevate õpetajate õpetajatööst ettekujutuse ja kutsevalikuga rahulolu faktoritele antud keskmiste hinnangute võrdlus

\begin{tabular}{|c|c|c|c|c|c|}
\hline \multirow[t]{2}{*}{ Faktorid } & \multicolumn{2}{|c|}{$\begin{array}{c}\text { Õpetajakoolituse } \\
\text { praktikandid }\end{array}$} & \multicolumn{2}{|c|}{$\begin{array}{c}\text { Kutseaastal olevad } \\
\text { õpetajad }\end{array}$} & \multirow[b]{2}{*}{$t$} \\
\hline & $M$ & $S D$ & $M$ & $S D$ & \\
\hline Rahulolu kutsevalikuga & 4,21 & 0,82 & 4,48 & 0,72 & $3,47^{* *}$ \\
\hline $\begin{array}{l}\text { Suured nõudmised ameti- } \\
\text { oskustele }\end{array}$ & 4,41 & 0,44 & 4,34 & 0,43 & $-1,52$ \\
\hline Sotsiaalne staatus ja palk & 2,51 & 0,73 & 2,6 & 0,71 & 1,25 \\
\hline
\end{tabular}

Märkus. ${ }^{* *} p<0,01$.

Erinevused esinesid ka kahe võrreldud grupi hinnangute pingeridades. Õpetajakoolituse praktikandid hindasid kõige olulisemaks faktorit Suured nõudmised ametioskustele ning see erines statistiliselt oluliselt kahest teisest faktorist (erinevus teisel kohal olevast faktorist Rahulolu kutsevalikuga, $t=$ $3,33, p<0,01$ ). Kõige madalamalt hinnatud faktori Sotsiaalne staatus ja palk ning faktori Rahulolu kutsevalikuga vahel oli samuti statistiliselt oluline erinevus, $t=24,1, p<0,001$. Kutseaastal olevad õpetajad hindasid aga kõige kõrgemalt faktorit Rahulolu kutsevalikuga ning see erines statistiliselt olulisel määral ülejäänud kahest faktorist, mis olid seotud ettekujutusega õpetajatööst (erinevus teisel kohal olevast faktorist Suured nõudmised ametioskustele, $t=$ $2,37, p<0,05)$. Samuti oli statistiliselt oluline erinevus kõige madalamalt hinnatud faktori Sotsiaalne staatus ja palk ning faktori Suured nõudmised ametioskustele vahel, $t=29,43, p<0,001$. 


\section{Arutelu}

Kasutades FIT-Choice’i skaala Eesti konteksti kohandatud ja lühendatud varianti, saadi õpetajakutse valiku motiivide osas nii õpetajakoolituse praktikantide kui ka kutseaastal olevate õpetajate puhul sarnane viiefaktoriline struktuur. Erinevus esines vaid ühes väites „Õpetajatöö võimaldab mul ühiskonda teenida”, mis paigutus õpetajakoolituse praktikantidel ja kutseaastal olevatel õpetajatel erinevatesse faktoritesse. Kutseaastal olevate õpetajate puhul asetus see väide sisuliselt sobivasse faktorisse Soov noorte jaoks kasulik olla ja ühiskonda teenida, kuid õpetajakoolituse praktikantide puhul sisuliselt ebasobivasse faktorisse Oluliste inimeste mõju. Erinevus kahe grupi vahel võib olla tingitud sellest, et õpetajakoolituse praktikantide kutsevalikul võib mõjutegur Võimalus ühiskonda teenida jääda neile sel hetkel veel arusaamatuks.

Võrreldes nii õpetajakoolituse praktikantide kui ka kutseaastal olevate õpetajate ettekujutust õpetajatööst ja rahulolu kutsevalikuga, ilmnes, et faktorites, mis olid seotud ettekujutusega õpetajatööst, esines erinevus mitme väite osas, kusjuures madalate kommunaliteetide tõttu tuli väited ühe või teise grupi faktoritest eemaldada. Selline väidete puudumine ühest või teisest faktorist tekitas olukorra, kus üks faktor tuli kahe grupi võrdluses nimetada teisiti - õpetajakoolituse praktikantide puhul Sotsiaalne staatus ja palk ning kutseaastal olevate õpetajate puhul Sotsiaalne staatus (arusaadavuse huvides nimetatakse seda faktorit edaspidi siiski kui Sotsiaalne staatus ja palk). Kahe grupi vaheline erinevus kahes faktoris Sotsiaalne staatus ja palk ning Suured nõudmised ametioskustele võis olla tingitud kahest põhjusest. Esiteks, kui lähtuda õpetamiskogemusest, on tegemist kahe erineva grupiga, st kutseaastal olevatel õpetajatel on juba lühiajaline õpetamiskogemus olemas, kuid õpetajakoolituse praktikantidel ei ole. Seetõttu võivad nad näha õpetajatööd erinevalt ning see võis tekitada ka erinevusi faktorstruktuurides. Teiseks, kuna FIT-Choice'i skaala originaalvariant sisaldas oluliselt rohkem väiteid kui käesolevas uurimuses kasutatud Eesti konteksti kohandatud ankeet, siis võis see põhjustada probleeme n-ö hea faktormudeli tekkimisel.

Õpetajakoolituse praktikantide ja kutseaastal olevate õpetajate kutsevaliku motiivide puhul leiti statistiliselt olulised erinevused viiest faktorist kahel: Sisemine motivatsioon ja tajutud ópetamisoskused ning Väline motivatsioon ja töö sobivus eraeluga. Selgus, et kutseaastal olevad õpetajad hindasid oma sisemist motivatsiooni ja tajutud õpetamisoskusi ning välist motivatsiooni ja töö sobivust eraeluga oluliselt kõrgemalt kui õpetajakoolituse praktikandid. Autorite arvates on see üsnagi loogiline tulemus, sest reaalselt asuvadki õpetajana tööle need inimesed, kelle sisemine motivatsioon ja hinnang oma tajutud õpetamisoskustele võib olla kõrgem ning kes ka näevad 
õpetajaelu sobivust pereeluga. Samas võib see tulemus viidata ka asjaolule, et õpetajakoolituse õppekavadel õpib üliõpilasi, kes tegelikult ei kavatsegi reaalselt õpetajana tööle minna, vaid kes on huvitatud ainult kõrghariduse omandamisest. Probleemile, et õpetajahariduse erialadele ülikoolides kandideerivad inimesed, kes ei ole piisavalt motiveeritud õpetajana tööle minema, on viidanud ka Riigikogu kultuurikomisjoni esimees Klaas, nimetades õpetajahariduses valitsevaid kitsaskohti (XII Riigikogu stenogramm, V istungjärk, 2013). Ots jt (2008) on osutanud, et õpetajakoolituse lõpetanutest läheb õpetajana tööle vaid kolmandik, mis viitab samuti asjaolule, et õpetajakoolituse erinevatel õppekavadel võib olla vähemal või rohkemal määral üliõpilasi, kes ei ole tegelikult piisavalt motiveeritud õpetajana tööle minema.

Saamaks teada, milliseid motiive üks või teine grupp kõrgemalt hindas, uuriti erinevusi ka kahe grupi sees. Õpetajakutse valiku motiivide osas kutseaastal olevate õpetajate ja õpetajakoolituse praktikantide hinnangute pingeread kattuvad. Nii andsid mõlemad grupid kõige kõrgema hinnangu faktori Sisemine motivatsioon ja tajutud õpetamisoskused puhul ning kõige madalama faktori Oluliste inimeste mõju puhul. Sarnastele tulemustele õpetajakutse valiku motiivide seadmisel pingeritta on jõudnud ka teised uurijad (Fokkens-Bruinsma \& Canrinus, 2012; Köning \& Rothland, 2012; Lin et al., 2012; Richardson \& Watt, 2006; Watt \& Richardson, 2007; Watt et al., 2012). On muidugi rõõmustav, et nii õpetajakoolituse praktikante kui ka kutseaastal olevaid õpetajaid on nende endi hinnangul kõige enam mõjutanud sisemise motivatsiooniga seotud motiivid ehk neile pakub õpetamine iseenesest huvi ja tekitab rahulolu. Lisaks kuulusid samasse faktorisse tajutud õpetamisoskustega seotud väited, mis näitab, et õpetajakutse valinud inimesed ning need, kes juba sellel elukutsel töötavad, tunnevad ise, et neil on eeldusi heaks õpetajaks kujuneda.

Mõlema grupi poolt kõige madalamalt hinnatud faktor Oluliste inimeste mõju viitab sellele, et nii õpetajakoolituse praktikandid kui ka kutseaastal olevad õpetajad on otsuse saada õpetajaks teinud pigem oma sisemisest huvist õpetajatöö vastu kui teiste inimeste (sõprade, perekonna) mõjutusel. Ka Watti ja Richardsoni (2007) uurimistulemused näitasid, et perekonna, sõprade ja töökaaslaste mõju õpetajakoolituse üliõpilaste kutsevalikul on väiksem kui teiste motivatsioonitegurite korral.

Võrreldes õpetajakoolituse praktikantide ja kutseaastal olevate õpetajate ettekujutusi õpetajatööst ja rahulolu kutsevalikuga, leiti statistiliselt oluline erinevus kolmest faktorist ühe puhul: Rahulolu kutsevalikuga. Kutseaastal olevad õpetajad hindasid rahulolu kutsevalikuga kõrgemalt kui õpetajakoolituse praktikandid, st et need, kes reaalselt ka õpetajana tööle lähevad, on rohkem rahul oma kutsevalikuga kui need, kes alles õpivad õpetajakoolituses. Vaadates erinevusi gruppide sees, ilmnes kõige kõrgemalt hinnatud faktori 
puhul erinevus. Õpetajakoolituse praktikandid hindasid kõige kõrgemalt faktorit Suured nõudmised ametioskustele, kuid kutseaastal olevad õpetajad pidasid kõige olulisemaks faktorit Rahulolu kutsevalikuga. Nii Watti ja Richardsoni (2007) kui ka Fokkens-Bruinsma ja Canrinuse (2012) uuringus osalenud õpetajakoolituse üliõpilased hindasid samuti kõrgelt rahulolu kutsevalikuga ja nõudmisi õpetajatööle.

Kõige madalamalt hinnatud faktori osas kahe grupi vahel erinevusi ei ilmnenud: nii õpetajakoolituse praktikandid kui ka kutseaastal olevad õpetajad olid kõige madalamalt hinnanud faktorit Sotsiaalne staatus ja palk. See tulemus ei tähenda tõenäoliselt aga seda, et õpetajatöö sotsiaalne staatus ja palk polegi uuringus osalenute jaoks olulised, vaid näitab pigem seda, et kuna need õpetajatöö aspektid ongi meie ühiskonnas vähetähtsad, siis ei saakski neil õpetajakoolituse praktikantide ja kutseaastal olevate õpetajate kutsevaliku motivatsioonitegurina suurt mõju olla. Õpetajatöö madal staatus ja väike palk on probleemiks ka teistes riikides, kus on saadud samaväärseid tulemusi (Fokkens-Bruinsma \& Canrinus, 2012; Lin et al., 2012; Watt \& Richardson, 2007).

\section{Kokkuvõte ja uurimuse piirangud}

Kokkuvõtteks võib öelda, et õpetajakoolituse praktikantide ja kutseaastal olevate õpetajate hinnangud erinesid kutsevalikut mõjutavate motivatsioonitegurite osas kolme faktori puhul kaheksast.

Uurimuse piirangutena võib välja tuua järgmised aspektid. Esiteks tuleb mainida valimi teatud määral väikest esinduslikkust: lasteaia- ja klassiõpetajad olid kutseaastal olevate õpetajate grupis arvukamalt esindatud kui õpetajakoolituse praktikantide grupis. See asjaolu võiski esile kutsuda erinevusi faktorites õpetajakoolituse praktikantide ja kutseaastal olevate õpetajate võrdlemisel. Teine uurimuse kitsaskoht on seotud kasutatud küsimustikuga. FITChoice’i originaalskaalaga (Watt \& Richardson, 2007) võrreldes jäeti Eesti konteksti kohandatud variandist erinevatel põhjustel välja mitmeid väiteid, mis muutis faktorstruktuuri tõlgendamise kohati keerulisemaks. Näiteks kui madalate kommunaliteetide tõttu tuli mõnest väitest loobuda, ei pruukinud teatud faktorisse piisavalt väiteid jätkuda ning sellega seoses vähenes ka faktorite arv. Samuti muutis mitmete väidete väljajätmine keerulisemaks võrdluse teiste teadlaste uurimistulemustega, sest tekkis vähem faktoreid. 


\section{Soovitused edasisteks uurimusteks ja uurimuse praktiline väärtus}

Läbitöötatud kirjanduse ja käesoleva uurimuse tulemuste põhjal tekkis edasiste uurimuste tarbeks mitmeid mõtteid. Nimelt võiks tulevikus veelgi rohkem mõelda õpetajate kutsevalikut mõjutavate motivatsioonitegurite põhjuslike-võrdlevate uuringute tegemisele, näiteks võrrelda erinevate erialade õpetajahariduse õppekavadel õppivaid üliõpilasi, et selgitada välja, milliste erialade üliõpilaste motivatsioon kutsevalikuks nõuab kõige enam tähelepanu. Kindlasti oleks oluline ja vajalik uurida ka õpetajate kutsevalikut mõjutavate motivatsioonitegurite seoseid teiste õpetajatööd mõjutavate teguritega (näiteks enesetõhususega), et saada rohkem teada, kuidas seostub õpetajakandidaadi algne motivatsioon teiste õpetajatööks vajalike eeldustega.

Artikli autorid arvavad, et nii õpetajakoolituse praktikantide kui ka kutseaastal olevate õpetajate kutsevalikut mõjutavate motivatsioonitegurite väljaselgitamine ning kahe grupi võrdlus annavad olulist informatsiooni nende kahe grupi motivatsioonitegurite erinevuste kohta. Uurimuse tulemused on sisendiks järgnevatele uurimustele, mis võimaldavad tõhustada parimate kandidaatide selekteerimist õpetajahariduse õppekavadele.

\section{Tänusõnad}

Uurimus on tehtud Euroopa Sotsiaalfondi EDUKO programmi (1.2.0302.09004) ning haridus- ja kasvatusteaduste doktorikooli (1.2.0401.09-0070) rahalisel toetusel.

\section{Kasutatud kirjandus}

Atkinson, J. W. (1957). Motivational determinants of risk-taking behavior. Psychological Review, 64(6), 359-372. http://dx.doi.org/10.1037/h0043445

Bandura, A. (1998). Self-efficacy: The exercise of control (2nd ed.). New York: W. H. Freeman and Company.

Berger, J-L., \& D’Ascoli, Y. (2012). Becoming a VET teacher as a second career: Investigating the determinants of career choice and their relation to perceptions about prior occupation. Asia-Pacific Journal of Teacher Education, 40(3), 317-341. http://dx.doi.org/10.1080/1359866X.2012.700046

Bruinsma, M., \& Jansen, E. P. W. A. (2010). Is the motivation to become a teacher related to pre-service teachers' intentions to remain in the profession? European Journal of Teacher Education, 33(2), 185-200. http://dx.doi.org/10.1080/02619760903512927 Eesti keele seletav sõnaraamat (2009). Külastatud aadressil http://www.eki.ee/dict/ekss/. Eesti õpetajahariduse strateegia 2009-2013 (2008). Külastatud aadressil http://www.hm.ee/index.php?048706. 
Eccles, S. J., \& Wigfield, A. (2002). Motivational beliefs, values, and goals. Annual Review Psychology, 53(1), 109-132.http://dx.doi.org/10.1146/annurev.psych.53.100901.135153

Elliot, A. J., \& Zahn, I. (2008). Motivation. In N. J. Salkind (Ed.), Encyclopedia of Educational Psychology (pp. 686-692). Thousand Oaks: Sage Publications Inc.

Fishbein, M., \& Ajzen, I. (1975). Belief, attitude, intention, and behavior: An introduction to theory and research. Reading: Addison-Wesley.

Fokkens-Bruinsma, M., \& Canrinus, E. T. (2012). The factors influencing teaching (FIT)choice scale in a Dutch teacher education program. Asia-Pacific Journal of Teacher Education, 40(3), 249-269. http://dx.doi.org/10.1080/1359866X.2012.700043

Gao, X., \& Trent, J. (2009). Understanding mainland Chinese student teachers' motivations for choosing a teacher education programmes in Hong Kong. Journal of Education for Teaching: International Research and Pedagogy, 35(2), 145-159. http://dx.doi.org/10.1080/02607470902771037

Jarvis, J., \& Woodrow, D. (2005). Reasons for choosing a teacher training course. Research in Education, 73, 29-35. http://dx.doi.org/10.7227/RIE.73.3

Jugović, I., Marušić, I., Ivanec, T. P., \& Vidović, V. V. (2012). Motivation and personality of preservice teachers in Croatia. Asia-Pacific Journal of Teacher Education, 40(3), 271-287. http://dx.doi.org/10.1080/1359866X.2012.700044

Kilinç, A., Watt, H. M. G., \& Richardson, P. W. (2012). Factors influencing teaching choice in Turkey. Asia-Pacific Journal of Teacher Education, 40(3), 199-226. http://dx.doi.org/10.1080/1359866X.2012.700048

Klassen, R. M., Al-Dhafri, S., Hannok, W., \& Betts, S. M. (2011). Investigating pre-service teacher motivation across cultures using the Teachers' Ten Statements Test. Teaching and Teacher Education, 27(3), 579-588. http://dx.doi.org/10.1016/j.tate.2010.10.012

Krips, H., Taimalu, M., Luik, P., \& Kukemelk, H. (2009). Estonian students' occupational preferences. Poster presentation in EARLI 2009 conference.

Krull, E. (2000). Pedagoogilise psühholoogia käsiraamat. Tartu: Tartu Ülikooli Kirjastus.

Köning, J., \& Rothland, M. (2012). Motivations for choosing teaching as a career: Effects on general pedagogical knowledge during initial teacher education. Asia-Pacific Journal of Teacher Education, 40(3), 289-315. http://dx.doi.org/10.1080/1359866X.2012.700045

Lin, E., Shi, Q., Wang, J., Zhang, S., \& Hui, L. (2012). Initial motivations for teaching: Comparison between preservice teachers in the United States and China. AsiaPacific Journal of Teacher Education, 40(3), 227-248. http://dx.doi.org/10.1080/1359866X.2012.700047

Loogma, K., Ruus, V-R., Talts, L., \& Poom-Valickis, K. (2009). Õpetaja professionaalsus ning tõhusama õpetamis- ja õppimiskeskkonna loomine: OECD rahvusvahelise oppetamise ja óppimise uuringu TALIS tulemused. Tallinn: Tallinna Ülikooli haridusuuringute keskus.

Marston, S. H. (2010). Why do they teach? A comparison of elementary, high school, and college teachers. Education, 131(2), 437-454.

Moran, A., Kilpatrick, R., Abbott, L., Dallat, J., \& McClune, B. (2001). Training to teach: Motivating factors and implications for recruitment. Evaluation and Research in Education, 15(1), 17-32. http://dx.doi.org/10.1080/09500790108666980

Organisation for Economic Co-operation and Development (OECD) (2005). Teachers matter: Attracting, developing, and retaining effective teachers. Paris: OECD. 
Organisation for Economic Co-operation and Development (OECD) (2011). Building a high-quality teaching profession: Lessons from around the world. Paris: OECD.

Ots, A., Vaher, K., Selliov, R., \& Laanoja, P. (2008). Ülevaade Eesti ópetajaskonnast. Külastatud aadressil www.hm.ee/index.php?popup=download\&id=8781.

Richardson, P. W., \& Watt, H. M. G. (2006). Who chooses teaching and why? Profiling characteristics and motivations across three Australian universities. Asia-Pacific Journal of Teacher Education, 34(1), 27-56. http://dx.doi.org/10.1080/13598660500480290

Roness, D., \& Smith, K. (2010). Stability in motivation during teacher education. Journal of Education for Teaching, 36(2), 169-185. http://dx.doi.org/10.1080/02607471003651706

Ryan, R. M., \& Deci, E. L. (2000). Intrinsic and extrinsic motivations: Classic definitions and new directions. Contemporary Educational Psychology, 25(1), 54-67. http://dx.doi.org/10.1006/ceps.1999.1020

Sinclair, C. (2008a). Initial and changing student teacher motivation and commitment to teaching. Asia-Pacific Journal of Teacher Education, 36(2), 79-104. http://dx.doi.org/10.1080/13598660801971658

Sinclair, C. (2008b). How can what we know about motivation to teach improve the quality of initial teacher education and its practicum? In P. A. Towndrow, C. Koh \& T. H. Soon (Eds.), Motivation and practice for the classroom (pp. 37-61). Rotterdam: Sense Publishers.

Tollefson, N. (2000). Classroom applications of cognitive theories of motivation. Educational PsychologyReview, 12(1),63-83.http://dx.doi.org/10.1023/A:1009085017100

Watt, H. M. G., \& Richardson, P. W. (2007). Motivational factors influencing teaching as a career choice: Development and validation of the FIT-Choice scale. The Journal of Experimental Education, 75(3), 167-202. http://dx.doi.org/10.3200/JEXE.75.3.167-202

Watt, H. M. G., \& Richardson, P. W. (2008). Motivations, perceptions, and aspirations concerning teaching as a career for different types of beginning teachers. Learning and Instruction, 18(5), 408-428. http://dx.doi.org/10.1016/j.learninstruc.2008.06.002

Watt, H. M. G., Richardson, P. W., Klusmann, U., Kunter, M., Beyer, B., Trautwein, U., \& Baumert, J. (2012). Motivations for choosing teaching as a career: An international comparison using the FIT-Choice scale. Teaching and Teacher Education, 28(6), 791-805. http://dx.doi.org/10.1016/j.tate.2012.03.003

Wigfield, A. (1994). Expectancy-value theory of achievement motivation: A development perspective. Educational Psychology Review, 6(1), 49-78.

http://dx.doi.org/10.1007/BF02209024

Wigfield, A., \& Eccles, J. (2000). Expectancy-value theory of achievement motivation. Contemporary Educational Psychology, 25(1), 68-81. http://dx.doi.org/10.1006/ceps.1999.1015

Woolfolk, A. (2010). Educational psychology (11th ed.). Global Edition. USA: Pearson Education, Inc.

XII Riigikogu stenogramm. V istungjärk. Neljapäev, 17. jaanuar 2013 kell 10.00. Olulise tähtsusega riikliku küsimuse „Ôpetajahariduse hetkeseis, probleemid ja ootused” arutelu. Külastatud aadressil http://www.riigikogu.ee/?op=steno\&stcommand= stenogramm\&date $=1358409472$. 


\title{
Factors motivating the choice of teaching as a career among student teachers and first-year teachers
}

\author{
Olivia Voltri ${ }^{\mathrm{a} 1}$, Piret Luik ${ }^{\mathrm{a}}$, Merle Taimalu ${ }^{\mathrm{a}}$ \\ ${ }^{a}$ University of Tartu, Institute of Education
}

\section{SUMMARY}

\section{Introduction}

In recent years, researchers have begun to show considerable interest in studying factors that motivate the choice of teaching as a career because, according to OECD data $(2005,2011)$, countries represented in the Thematic Review on Teacher Policy have developed problems a) related to the ageing of teachers, b) bringing new qualified teachers into schools, and c) getting teachers to remain in the teaching profession. Studies show that Estonian teachers are older than the international average (Eesti õpetajahariduse strateegia, 2008; Loogma, Ruus, Talts, \& Poom-Valickis, 2009). Furthermore, in the Estonian context, it is worth highlighting the low public acknowledgement of the teaching profession in the media, and remuneration for teachers that does not correspond to the importance of this profession for the development of society - this results in the profession having a low reputation (Eesti oppetajahariduse strateegia, 2008). The statistics from the past decade indicate that less and less young people choose teaching as a career (Ots, Vaher, Selliov, \& Laanoja, 2008), and studies show that the choice of teaching as a profession is at the bottom of the list for young people (Krips, Taimalu, Luik, \& Kukemelk, 2009). Although in general, the number of graduates from teacher training programs could be sufficient to cover the needs of kindergartens and schools, only one third of those graduating from teacher training proceed to work in their chosen field (Ots et al., 2008). Factors that motivate student teachers and novice teachers to choose teaching as a career provides input for better organizational and curricular planning in teacher training programmes, arranging better recruitment of teachers, and making better decisions concerning teacher training at the government level (Lin, Shi, Wang, Zhang, \& Hui, 2012; Watt \& Richardson, 2007).

On the basis of different studies it can be concluded that there are various motivating factors for choosing teaching as a career, encompassing

1 Institute of Education, Faculty of Social Sciences and Education, University of Tartu, Salme 1a, 50103 Tartu, Estonia, olivia.voltri@ut.ee 
intrinsic, extrinsic and altruistic factors (Marston, 2010; Sinclair, 2008b; Watt \& Richardson, 2007, 2008). Research also indicates that several simultaneous factors, rather than one single factor, appear to influence a young person's choice of teaching as a career (Richardson \& Watt, 2006; Sinclair, 2008a).

A summary of research outcomes (Fokkens-Bruinsma \& Canrinus, 2012; Richardson \& Watt, 2006; Sinclair, 2008a; Watt \& Richardson, 2007; Watt et al., 2012) indicates that the factors motivating student teachers to choose teaching as a career are mostly intrinsic, rather than extrinsic. It has also been determined that factors that motivate teachers to choose the profession of teaching are associated with their satisfaction with teaching as a career and the extent to which they plan to stay true to their chosen profession (Watt \& Richardson, 2008). The purpose of the present study was to compare the factors that motivated student teachers and first-year teachers to choose teaching as a career.

The research questions were:

1) What differences are there in the structure of the motivating factors for student teachers and first-year teachers?

2) What differences are there in the factors motivating student teachers and first-year teachers in their choice of career?

3) Which motivating factors are more important for student teachers and which for first-year teachers in their choice of career?

\section{Method}

The present study applied a causal-comparative research design because the authors of the article compared two groups of subjects and assumed that the cause of differences already existed between the groups of individuals. The sample consisted of 396 respondents, 207 of whom were teachers in their induction year and 189 were student teachers. The study enlisted student teachers and teachers in their induction year from the University of Tallinn $(143 ; 36 \%)$ and the University of Tartu $(252 ; 64 \%)$.

The data was collected using a questionnaire based on the Watt and Richardson (2007) scale of Factors Influencing Teaching Choice (abbreviated as FIT-Choice Scale). The FIT-Choice Scale (Watt \& Richardson, 2007) was developed on the basis of expectancy-value theory (Eccles et al., 1983, cited in Wigfield, Eccles, 2000; Tollefson, 2000), and after being adjusted for the Estonian context, comprised 38 items: motivation for choosing teaching as a career (26 items), and perceptions about teaching and satisfaction with career choice (12 items).

The study was conducted in 2010 and 2012. Student teachers were sent the questionnaire at the beginning of their pedagogical school practice, 
and first-year teachers were sent the questionnaire at the beginning of their induction year. In Estonia, the first year of teaching is an ,induction year”, during which they need to develop a teaching portfolio, and participate in university meetings and seminars while they are beginning teachers in schools or kindergartens.

Data was analysed using an exploratory factor analysis and $t$-test.

\section{Results and discussion}

Applying the FIT-Choice Scale (adjusted for the Estonian context) to the motives for choosing teaching as a career identified a similar five-factor structure for both student teachers and first-year teachers (there was a difference in only one item). On the other hand, the comparison of the perceptions of student teachers and first-year teachers about teaching, as well as their satisfaction with their choice of career, identified differences in several items concerning factors associated with perceptions about teaching.

A comparison of the motives for choosing career among student teachers and first-year teachers showed statistically significant differences in two factors out of five: intrinsic motivation and perceived teaching skills and extrinsic motivation and compatibility of work with private life. It appeared that firstyear teachers rated their intrinsic motivation and perceived teaching skills significantly higher than student teachers. The items of the factor extrinsic motivation and compatibility of work with private life were also rated higher by first-year teachers than student teachers. However, an analysis of the differences within the two groups showed an overlap between the rankings of both first-year teachers and student teachers. That is, both groups had given the highest rank to the factor intrinsic motivation and perceived teaching skills and the lowest rank to the factor influence of important people. Similar results have been obtained by other researchers studying the raking of motives for choosing teaching as a career (Fokkens-Bruinsma \& Canrinus, 2012; Richardson \& Watt, 2006; Watt \& Richardson, 2007; Watt et al., 2012).

A comparison of student teachers and first-year teachers regarding satisfaction with teaching as a career, and perceptions about teaching, showed a statistically significant difference for one of the three factors: satisfaction with choice of career. First-year teachers rated their satisfaction with their choice of career higher than student teachers. Analysis of the differences within the groups showed that there was a difference in the highest-ranked factor. Student teachers gave the highest ranking to the factor high vocational skills, whereas first-year teachers considered the most important factor to be 
satisfaction with choice of career. The student teachers participating in the Watt and Richardson (2007) and Fokkens-Bruinsma and Canrinus (2012) studies also valued highly their satisfaction with their choice of career and the requirements of the teaching profession.

There were no differences between the two groups for the lowest-ranked factor - both student teachers and first-year teachers gave the lowest ranking to the factor social status and salary. The low status and low salaries for the teaching profession are problematic in other countries as well, where similar results (Fokkens-Bruinsma \& Canrinus, 2012; Watt \& Richardson, 2007) have been identified.

The authors of the article are of the opinion that an overview of the factors that influence the motivation of the choice of teaching as a career for both student teachers and first-year teachers, and the comparison of these two groups, could be helpful in better organizing the acceptance of new students into teacher education curricula, motivating students to seek employment as teachers, and motivating first-year teachers to remain true to their chosen profession.

Keywords: teaching as a career choice, motivational factors, FIT-Choice, induction year and teacher training, causal-comparative research 